Katarzyna Maria DŹWIGAŁA*

\title{
ROMANOS THE MELODIST AS A TEACHER OF THE PEOPLE IN THE STRUGGLE AGAINST HERESIES
}

Saint Romanos the Melodist was born in the second half of the fifth century in Emesa, Syria, that was at the time bilingual, both Syriac and Greek were commonly used. We can assume that the poet was fluent in these two languages since his youth. After serving as a deacon in Beirut, at the turn of the fifth and the sixth century he came to Constantinople, where he was assigned to the church of the Virgin in the Kyrou district. Certainly, during his lifetime he was already well-known as a writer of liturgical hymns and likely became a member of the Palace circle ${ }^{1}$.

The writings of Romanos the Melodist, though they contain only poetry, are without a doubt an evidence of the intense struggle against heresies, even those rejected by the Church many years before. In the hymns of Romanos, we find a censure against views of many different heretic groups. But this censure is always accompanied by the presentation of the doctrine of the Church in particular points and by the instruction what the people should believe in. In the writings of Romanos, there are terms and phrases derived directly from the documents of the Church.

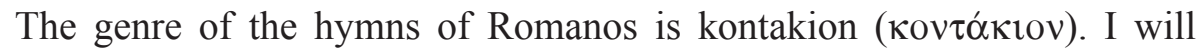
shortly characterize it in order to more fully understand the struggle of saint Romanos against heresies. Kontakia were poetic homilies consisting of about 20 stanzas. They were sung by a cantor and a choir during the night vigil in the cathedral office, and during orthros in the monastic office ${ }^{2}$. It is worth noting that the hymns were quite long and the poet had to use many means to

\footnotetext{
* Katarzyna Maria Dźwigała, PhD candidate in the Institute of Classical Studies, Faculty of Polish Studies, University of Warsaw; e-mail: katarzynadzwigala@o2.pl.

${ }^{1}$ Cf. M. Carpenter, Introduction, in: Kontakia of Romanos, Byzantine Melodist, vol. 1: On the Person of Christ, ed. and trans. M. Carpenter, Columbia (Missouri) 1970, xiv.

${ }^{2}$ Cf. A. Lingas, The Liturgical Place of the Kontakion in Constantinople, in: Liturgy, Architecture and Art in Byzantine World, ed. C.C. Akentiev, vol. 1, Saint Petersburg 1995, 52; J. Koder, Einleitung, in: Romanos Melodos, Die Hymnen, ed. and trans. J. Koder, vol. 1, Stuttgart 2005, 21; G. Frank, Romanos and the Night Vigil, in: Byzantine Christianity, ed. D. Krueger, vol. 3, Minneapolis 2006, 61 and 63; R.J. Schork, Sacred Song from the Byzantine Pulpit: Romanos the Melodist, Gainesville 1995, 6.
} 
make his kontakion more dynamic. The homiletic function of the kontakia is the reason why the poet raises the theological issues that were discussed with heretics. In the face of the doctrinal controversies, it was a duty of the preacher to instruct the assembled people in what they should believe. Many formal features supported didactic role of the kontakia. Quite long stanzas, having from a few to a dozen verses, always ended with identical or similar refrain

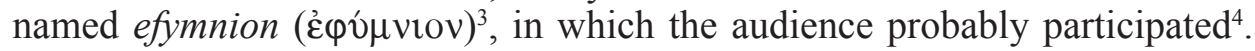
This measure certainly was to sustain attention of the audience. We can assume that the melody was also an important element of the hymns, but original music of the kontakia has not been preserved ${ }^{5}$. In addition to the melody, there existed also a complex metrical structure that influenced the perception of the hymns and gave them dynamism. The simple language of the Greek koine facilitated the comprehension of the hymns by the people to which the poems of classicizing Christian poets and theological tractates and homilies of the Church Fathers were inaccessible. The style of Romanos is full of figures of speech - it made the understanding of theological issues undoubtedly easier.

It is worth noting, that there have not been preserved any kontakia from the time before Romanos Melodos, and the invention of the genre is attributed to him. Among the researchers, there is a discussion about the origin of the kontakion and the reasons why the new genre appeared. Actually, there prevails an opinion that the genre has Syriac roots ${ }^{6}$. It was created by the synthesis of Syriac genres of Christian poetry and by the transmission of them to the Greek. The emergence and the development of the kontakion could be explained by the flourishing of the liturgy in the sixth century: new splendid churches were built, which stimulated the expansion of liturgy connected to them. There was a need for new poetry and music, suitable for the new conditions. And what we can conclude from what has been preserved, is that before the sixth century there existed no considerable collection of the Christian poetry proper for the use during the worship. When the Christianity became a predominant religion, there appeared also a need to reach the uneducated listeners with the Christian doctrine; and kontakion seemed to be a very attractive form for this purpose.

The way of conducting the narration in the hymns is also very important to present how Romanos the Melodist instructed the faithful. Most of the hymns are based on the biblical themes but the poet writes quite freely within the framework of the Scriptures. The narration and the dialogs of the characters beside the homiletic stanzas and the prayers are also present. Saint Romanos frequently encloses in the vivid story the censure of those who undermine the

${ }^{3}$ Cf. E. Wellesz, A History of Byzantine Music and Hymnography, Oxford 1962, 180.

${ }^{4}$ Cf. J. Koder, Imperial propaganda in the Kontakia of Romanos the Melode, DOP 62 (2008) 288.

${ }^{5}$ Cf. O. Strunk, Essays on Music in the Byzantine World, New York 1977, 158.

${ }^{6}$ On the Syriac roots of kontakion see: W. Petersen, The Dependence of Romanos the Melodist upon the Syriac Ephrem: Its Importance for the Origin of the Kontakion, VigCh 39 (1985) 171-197; S. Brock, Syriac and Greek Hymnography: Problems of Origin, StPatr 16 (1985) 77-81. 
doctrine of the catholic Church, and explains what the Christians gathered for the worship should believe in. In this article, I want to present the following hymns in which the references to heresies appear: On the Nativity I, On the Marriage at Cana, On the Presentation in the Temple and On the Woman of Samaria. I will point out also the means used by the poet to instruct listeners of his hymns and to teach the doctrine of the Church.

1. The heresies in the times of Romanos the Melodist. During the lifetime of Romanos the Melodist (he died after 555) ${ }^{7}$ the most troublesome heresy in the Roman Empire was the Monophysite movement. Although the teaching of the divine and human nature of Christ was formulated in 451 at the Council of Chalcedon, we can say that initially it brought rather the divisions, than the agreement. Different groups of Monophysites did not want to accept the council's formula about the two natures of Christ: divine and human. They regarded it as secretly Nestorian and inconsistent with the teachings of Cyril of Alexandria. Egypt, Ethiopia, and a part of Syria separated themselves from the Catholic church. Emperor Justinian, in the face of dangers of invasions, tried to strengthen the Empire by restoring the unity of the Church. But the attempts to reconcile the Catholics and the Monophysites, which culmination was convening the Council in Constantinople in 553, did not bring expected result.

The difficult religious situation of the Empire was undoubtedly a serious problem of Justinian and the Catholic Church. In the writings of Romanos the Melodist, we can find the echoes of the fierce discussions of the theologians of this period, but in a much easier form. The poet inserts into the stories, based on the themes from the Bible, plain explanations of the complex theological issues, trying to bring them closer to his listeners. I will show it on the chosen examples. The hymnographer raises the issues not only connected with Monophysitism but also those formulated by the Church and being commonly accepted as early as in the fourth century, for example: the doctrine about the Holy Trinity or consubstantiality of God the Father and God the Son. In this way, kontakion becomes a sort of plain lecture on the teaching of the Church ${ }^{8}$.

2. The teaching hidden behind the poetry. At the beginning I would like to present a fragment from the most famous hymn of Romanos the Melodist - On the Nativity I:

${ }^{7}$ Cf. J. Grosdider de Matons, Hymne des dix vierges (1 ${ }^{e r}$ Hymne), in: Romanos le Mélode: Hymnes, tome V: Nouveau Testament (XLVI-L), et Hymnes de circonstance (LI-VI), éd. J. Grosdider de Matons, SCh 283, Paris 1981, 276-286; Koder, Einleitung, p. 30-31.

${ }^{8}$ On the heresies in the time of the emperor Justinian see: A. Grillmeier, Christ in Christian Tradition, vol. 2, part 2: The Church of Constantinople in the sixth century, London 1995 (especially p. 513-523 on the christological views of Romanos). 
"Jesus the Christ and truly our God

Secretly touched his mother's mind

Saying, «Bring in those I have brought by my word (ov̀

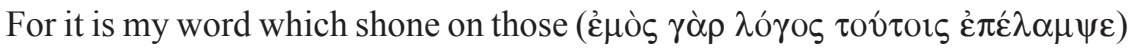

who were seeking me.

To the senses it is a star,

But to the mind a power»"'.

Already at the beginning of the quoted strophe the narrator ensures the listeners that Jesus is "truly our God", refuting in this way heresies that deny the Divinity of the Christ. Afterwards, interesting words appear in the text on the divine action of Jesus being an infant, furthermore, spoken by himself. Jesus says to His mother Mary to let Magi enter the cave where he was born, as we read in the quotation above. Such an utterance of the Child Jesus clearly points out what are the Christological opinions of the author of the hymn: he has no doubts that Jesus in human flesh remained the God and preserved His divine attributes. The star, which led Magi to Bethlehem, is the visible form of the word of Jesus. Here, saint Romanos not only explains the Scriptures but also tries to enclose in his preaching some theological knowledge. Because the words are spoken by Jesus himself, they become more reliable to the listeners. The author does not leave a space for a question whether Jesus as a child was the same person as God the Son, but he gives a voice to the character from the hymn in order to explain it himself, according to the teaching of the Church. The poetic story of the star becomes for the simple listeners an instruction that Jesus in human flesh is also fully the God in one person. We can see in what manner the author encloses the teaching on theological issues in his writings and how it is hidden behind the poetry. It is not easy to catch fully the sense of the strophe, but it also left certainly a concrete image in the minds of the listeners, which made the memorizing of some truths easier.

3. Using the theological terms. Although the doctrine of the Church about the consubstantiality of God the Father and God the Son was formulated by the Church nearly two hundred years before the origin of the kontakia of Romanos, we find in them reference to it. In the hymn On the Marriage at Cana Jesus says to his mother:

"That they might know with certainty the glory of my Father,

And His will, for he desires that in every way

I be glorified along with Him by all men.

For what He who engendered me has done, these things I also do,

Since I am consubstantial with Him and His spirit

${ }^{9}$ Romanos Melodos, Cantica 1, 8, 1-6, ed. P. Maas - C.A. Trypanis: Sancti Romani Melodi Cantica, Oxford 1963, 2-3, transl. E. Lash, On the Life of Christ: St. Romanos the Melodist, San Francisco 1995, 6. 


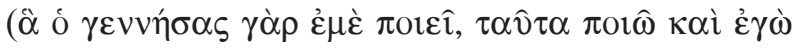

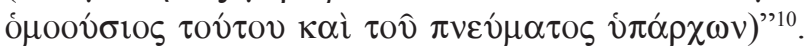

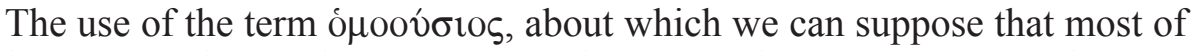
the listeners understood its meaning only intuitively, is an attempt to bring it closer to the people. The speech of Jesus concerns the equivalence of Him and God the Father: it is clearly said that Son of God is not in any way inferior to Father, as Arians claimed. Although Arianism was rejected much earlier and it was not a problematic issue in the sixth century, saint Romanos reminisces on it and explains one of the basic rule of the faith.

4. Christological issues in the eyes of the women. In some of the hymns in the description of the evangelical scenes, Romanos the Melodist finds a space to expand theological reflections on the relation between divine and human nature of Jesus. The crisis in the Church in the Roman Empire in the sixth century, connected with the dispute between Catholics and Monophysites, resulted in the strong need to enclose the explanation of the Christological issues in the homily. In the two kontakia, the poet presents similar thoughts of the women appearing in the Gospel on who is Jesus. The first of this characters is the mother of God, which in the hymn On the Presentation in the Temple has a mind full of anxiety and doubts about what should be her attitude towards her son. The dramatic character of this scene is well illustrated by the one question from the monologue of Mary, in Greek it sounds exceptionally concisely:

"Shall I suckle, you or give you glory?

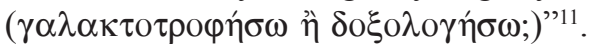

The example of the whole speech of Mary is a very illustrative lecture on the rules of the faith. Her doubts on who her son is are for the poet a pretext to add to his narrative an internal speech of one of the persons appearing in the scene of the Presentation in the Temple, which is silent in the Scriptures. Mary is presented as a character torn between conflicting emotions, what certainly makes the story more vivid. The contents of her considerations are however difficult Christological issues that in the times of Romanos the Melodist have been discussed by the theologians for a few hundred years. The hymnographer tries to explain the teachings of the Church on the relation of the divine and human nature of Christ in a way intelligible to the uneducated listeners.

The similar speech of a woman from the kontakion of Romanos appears also in the hymn On the woman of Samaria, which I would like to discuss at length. The poet presents biblical themes quite truly, without adding any other persons, but by expanding the dialog between Jesus and the Samaritan woman,

${ }^{10}$ Ibidem 7, 15, 4-8, ed. Maas - Trypanis, p. 54, transl. Carpenter, Kontakia of Romanos, vol. 1, p. $72-73$.

${ }^{11}$ Ibidem 4, 4, 7, ed. Maas - Trypanis, p. 29, transl. Lash, p. 29. 
in which he inserts Christological reflections. Thoughts on the nature of Jesus start with the following verses:

"the holy woman $[\ldots]$

longed even more

to discover what and who was the one at the well,

and perhaps she was in the grip, not unreasonably, of thoughts like these,

«Is it God or man at whom I am looking? A being of heaven or of earth?

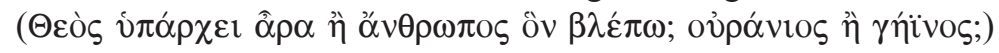

For see, he makes the two known to me in one.

He is thirsty, yet gives drink, he learns, yet predicts»"'12.

In the Gospel, Christ reveals to this woman the mystery, that he is an expected messiah. In the hymn of Romanos the Melodist, the narrative aiming to present these words of Jesus becomes an occasion to ask a question, who Jesus is, in the context of theological controversies. The woman testifies the fullness of his human nature, emphasizing that Jesus in appearance entirely resembles a human and, additionally, he is exhausted from the journey and the heat, and wants to drink. She points out also, that he has divine attributes: he gives the spiritual drink and has superhuman knowledge. The antitheses compiling the opposing features of Jesus underline the exceptionality of His person, and build a dramatic tension, which characterizes the hymns of Romanos. In the following stanzas, the poet continues mentioning the opposites:

"Is he then of heaven yet bears an earthly form?

If then, being God and mortal, he has been revealed to me as human [...]

but for the Invisible, who is now seen, to accuse me and rebuke me

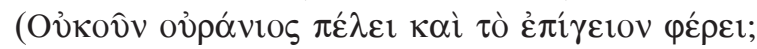

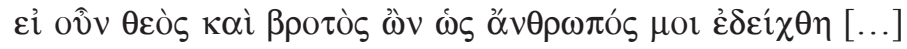

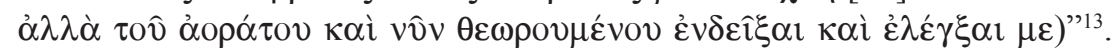

The words „being God and mortal” are the clear example of the teaching of catholic orthodoxy in the opposition to Monophysitism. The poet explicitly states that Jesus has two natures: divine and human, and he preserves attributes proper to them.

The monologue of the Samaritan woman ends with a question:

"Son of a mortal, as I see you, Son of God, as I understand you.

Enlighten my mind, Lord, teach me

Who you are" 14 .

The question of the woman is in the intention of the author a question of the people participating in the worship, asked in the context of the lasting

\footnotetext{
${ }^{12}$ Ibidem 9, 15, 1-7, ed. Maas - Trypanis, p. 69-70, transl. Lash, p. 69.

${ }^{13}$ Ibidem 9, 16, 1-2 and 5, ed. Maas - Trypanis, p. 70, transl. Lash, p. 70.

${ }^{14}$ Ibidem 9, 17, 1-3, ed. Maas - Trypanis, p. 70, transl. Lash, p. 70.
} 
discussions with Monophysites: what the faithful Christians should believe in, who is right in a dispute, how the plain human can understand the essence of the conflict? Samaritan woman becomes a bearer of the good tidings and a teacher of theology, when she claims to the people:

„Elders and youths, young men and maidens, run to the well [...]

There I saw a man, whom one should not call a man, for his works are God's

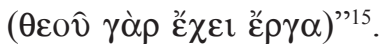

The theology included in the kontakia of Romanos the Melodist is rather plain. The poet does not try to discuss with the heretics: he thinks his aim is to preach the doctrine of the Church on issues that were in dispute in the past, or are discussed in his times. Instructing, in intelligible way, on issues with which the partakers of the councils dealt before, is the fulfillment of the sung homilies - kontakia. The hymnographer tries to present in an understandable language difficult theological issues, instructing listeners, what they should believe in when faced with lasting doctrinal controversies. In some places, the poet presents the opinions considered by the Church as false to refute them. Usually, however, he only presents the proper teachings. Many means serve to make the instruction easier and focus the attention of the listeners: mainly the dialogical form of most of the kontakia and giving the voice to the biblical characters. The kontakia of Romanos the Melodist certainly are a testimony of the struggle of the Church against heresies, and an interesting example of the echo of this conflict in the pastoral care of the plain Christians.

\section{(Summary)}

The article raises an issue of the didactic role of the Greek ecclesiastical hymns - the kontakia - in the context of the struggle of the Church in the sixth century against heresies. In the kontakia of Romanos the Melodist, who was the most prominent author of the hymns of that genre and probably a creator of the genre, we find numerous echoes of the struggles against heresies from the past centuries and from the lifetime of the poet. St. Romanos, when he writes his sung homilies, aims at the defence of the faithful assembled in the church against heretical views and at the instructing them what is the teaching of the Church. The hymnographer tries to present the difficult theological issues using the language understandable for the common Christians and make the hymn more attractive and memorable. The article shows on the examples the heresies against that Romanos the Melodist struggled and the measures he used.

\footnotetext{
${ }^{15}$ Ibidem 9, 20, 5 and 7, ed. Maas - Trypanis, p. 72, transl. Lash, p. 71.
} 


\section{ROMAN MELODOS JAKO NAUCZYCIEL LUDU W WALCE Z HEREZJAMI}

\section{(Streszczenie)}

Artykuł porusza kwestię dydaktycznej roli greckich hymnów kościelnych - kontakionów - w kontekście walki Kościoła w VI w. z herezjami. W kontakionach Romana Melodosa, będącego najwybitniejszym twórcą tego typu hymnów, a także hymnografem, dzięki któremu najprawdopodobniej powstał ten gatunek, znajdziemy liczne echa zmagań z herezjami przez kilka poprzedzających wieków aż do czasu życia poety. Św. Roman pisząc swe śpiewane homilie stawia sobie za cel obronę zgromadzonych w kościołach wiernych chrześcijan przed heretyckimi poglądami oraz pouczenie ich, jaka jest nauka Kościoła. Hymnograf stara się przedstawić trudne teologiczne zagadnienia językiem zrozumiałym dla przeciętnych wiernych, a także uczynić przekaz atrakcyjnym i zapadającym w pamięć. Artykuł na wybranych przykładach przedstawia herezje, które zwalczał Roman Melodos oraz wykorzystywane przez poetę środki.

Key words: Romanos the Melodist, kontakion, Byzantine hymnography, homily, heresy.

Słowa kluczowe: Roman Melodos, kontakion, hymnografia bizantyjska, homilia, herezja.

\section{BIBLIOGRAPHY}

\section{Sources}

Romanos Melodos, Cantica, ed. P. Maas - C.A. Trypanis: Sancti Romani Melodi Cantica, Oxford 1963, transl. by E. Lash, On the Life of Christ: St. Romanos the Melodist, San Francisco 1995; transl. by M. Carpenter, Kontakia of Romanos, Byzantine Melodist, vol. 1: On the Person of Christ, Columbia (Missouri) 1970.

\section{Literature}

Brock S., Syriac and Greek Hymnography: Problems of Origin, StPatr 16 (1985) 77-81.

CARpenter M., Introduction, in: Kontakia of Romanos, Byzantine Melodist, vol. 1: On the Person of Christ, ed. and trans. M. Carpenter, Columbia (Missouri) 1970, xiii-xxxvi.

Frank G., Romanos and the Night Vigil, in: Byzantine Christianity, ed. D. Krueger, vol. 3, Minneapolis 2006, 59-78.

Grillmeier A., Christ in Christian Tradition, vol. 2, part 2: The Church of Constantinople in the sixth century, London 1995.

Grosdider de Matons J., Hymne des dix vierges (1 $1^{e r}$ Hymne), in: Romanos le Mélode: Hymnes, tome V: Nouveau Testament (XLVI-L), et Hymnes de circonstance (LI-VI), éd. J. Grosdider de Matons, SCh 283, Paris 1981, 271-295.

Koder J., Einleitung, in: Romanos Melodos, Die Hymnen, ed. and trans. J. Koder, vol. 1, Stuttgart 2005, 9-48.

KoDER J., Imperial propaganda in the Kontakia of Romanos the Melode, DOP 62 (2008) 275-291. 
Lingas A., The Liturgical Place of the Kontakion in Constantinople, in: Liturgy, Architecture and Art in Byzantine World, ed. C.C. Akentiev, vol. 1, Saint Petersburg 1995, 50-57.

Petersen W., The Dependence of Romanos the Melodist upon the Syriac Ephrem: Its Importance for the Origin of the Kontakion, VigCh 39 (1985) 171-197.

Schork R.J., Sacred Song from the Byzantine Pulpit: Romanos the Melodist, Gainesville 1995.

STRUNK O., Essays on Music in the Byzantine World, New York 1977.

Wellesz E., A History of Byzantine Music and Hymnography, Oxford 1962. 
